\title{
ANALISIS RENCANA INVESTASI AKTIVA TETAP TERHADAP PERLUASAN USAHA PADA PT. TASPI TRD COY DI KOTA MAKASSAR
}

\author{
SUDIRMAN ABDI \\ Fakultas Agama Islam Universitas Indonesia Timur Makassar \\ Jl. Rappocini Raya No. 171-173 Kota Makassar 90222 \\ Email: sudirmanabdi@gmail.com
}

\begin{abstract}
:
Investment plan undertaken by PT. Taspi TRD COY is an appropriate decision to improve its business. This policy is taken to compensate and meet consumer demand as well as to increase revenue. Based on the calculation of the analytical method used in assessing the feasibility of investment to be conducted by PT. Taspi TRD COY turned out to show the results of a positive calculation and declared eligible for immediate realized because it is considered to provide benefits for the company. Analysis of investment feasibility at PT. Taspi TRD COY can be used as a basis in assessing any proposed investment proposals. Result of calculation from Net Present Value method show positive result that is equal to Rp 676.859.406,8, -, or in other words fund equal to $R p$ 3,600,000,000, - can generate present value of cash flow equal to $R p 4,276,859,407$, - which means this investment deserves to be accepted.
\end{abstract}

Keywords: Asset Investment, Business Expansion

\section{PENDAHULUAN}

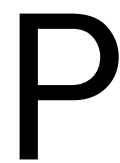

enanaman modal atau investasi merupakan unsur vital dalam tahapan perencanaan, pelaksanaan awal usaha, dan pengembangan usaha. Oleh

sebab itu, investasi harus mendapatkan perhatian yang serius. Di samping itu, persoalan investasi senantiasa melekat pada operasional perusahaan, baik karena desakan untuk meningkatkan efisiensi biaya maupun waktu.

Tujuan utama dari suatu investasi adalah untuk memperoleh berbagai manfaat pada waktu yang akan datang. Manfaat tersebut dapat berupa finansial maupun nonfinansial, dalam arti manfaat finansial berupa laba atau profit dan nonfinansial berupa terbukanya lapangan pekerjaan baru. Hal ini juga akan sangat membantu program pemerintah dalam mengatasi masalah pengangguran. Akan tetapi tidak semua investasi yang dilakukan baik oleh pihak pemerintah maupun pihak swasta dapat memberikan hasil seperti yang diharapkan. Kegagalan atau kerugian akibat investasi bisa saja terjadi.

Untuk mengantisipasi kemungkinan terjadinya kegagalan atau kerugian akibat investasi yang akan kita laksanakan, maka hendaknya terlebih dahulu dilakukan suatu penilaian kelayakan investasi. Hal ini dimaksudkan untuk menilai investasi yang akan dilaksanakan di masa mendatang. Penilaian di sini tidak lain 
adalah untuk memberikan rekomendasi apakah investasi tersebut layak dilaksanakan atau sebaliknya.

Penilaian investasi dilakukan untuk mengidentifikasi masalah di masa yang akan datang, sehingga dapat menghindari kemungkinan melesetnya tujuan yang ingin dicapai dari investasi tersebut. Di dalam penilaian investasi akan diperhitungkan peluang dan hambatan investasi terhadap usaha yang akan dijalankan. Jadi, penilaian investasi diharapkan dapat menjadi pedoman atau arahan terhadap investasi yang akan dilaksanakan. Penilaian investasi tersebut dapat dilakukan dengan menggunakan berbagai metode antara lain Payback Period (PP), Net Present Value (NPV), dan Internal Rate of Return (IRR)..

PT. Taspi TRD COY adalah salah satu perusahaan yang bargerak di bidang jasa angkutan penumpang dan angkutan barang (angkutan darat). Sebagaimana yang kita ketahui bahwa pada perusahaan yang bergerak di bidang jasa angkutan, investasi dalam aktiva tetap pada umumnya mempunyai nilai yang cukup besar khususnya aktiva tetap yang akan digunakan sebagai sarana utama dalam pelayanan jasa angkutannya.

Sebagai perusahaan yang unit usahanya memberikan jasa pengangkutan, maka PT. Taspi TRD COY dalam operasinya menggunakan aktiva tetap berupa kendaraan (bus) dalam jumlah yang cukup besar. Namun seiring dengan berjalannya waktu, kendaraan-kendaraan yang dimiliki akan mengalami penyusutan dan tentu saja akan berpengaruh terhadap kenyamanan konsumen yang menggunakan jasa angkutannya, sedangkan yang kita ketahui bahwa konsumen lebih cenderung untuk memilih fasilitas yang terbaru dari apa yang ditawarkan oleh perusahaan angkutan. Untuk itu PT. Taspi TRD COY diharapkan dapat memenuhi kebutuhan konsumen dengan melakukan investasi aktiva tetap. Investasi ini dilakukan dengan mengadakan penggantian atau penambahan armada bus.

Dari hasil pengamatan awal, diketahui kondisi usaha pengangkutan PT. Taspi TRD COY dapat dilihat pada tabel 1.

Tabel 1. Nilai Investasi PT. Taspi TRD COY Tahun 2014 - 2016

\begin{tabular}{c|ccc}
\hline Tahun & Jumlah Armada & Nilai Investasi & Laba / Rugi \\
\hline 2014 & 35 unit & Rp 42.000.000.000,- & Rp 91.690.125,- \\
2015 & 37 unit & Rp 44.400.000.000,- & Rp 98.822.500,- \\
2016 & 40 unit & Rp 48.000.000.000,- & Rp 115.700.000,- \\
\hline
\end{tabular}

Sumber : PT. TASPI TRD COY Makassar

Rencana perluasan atau ekspansi ini dilakukan dengan mengadakan penambahan armada bus sebanyak 3 (tiga) unit armada yang diperkirakan 
menelan biaya sebesar Rp 3.600.000.000,- di mana sumber dananya berasal dari modal sendiri dan sebagian dari pinjaman dari Bank. Dengan adanya penambahan investasi ini pihak perusahaan mengharapkan adanya peningkatan laba.

Berdasarkan uraian di atas, maka penulis tertarik untuk mengadakan penelitian pada PT. TASPI TRD COY dengan judul "Analisis Rencana Investasi Aktiva Tetap Terhadap Perluasan Usaha Pada PT. Taspi TRD COY di Kota Makassar." Dengan meninjau hal di atas, adapun permasalahan yang dapat penulis rumuskan adalah: "Bagaimana kelayakan rencana investasi aktiva tetap terhadap perluasan usaha pada PT. TASPI TRD COY di kota Makassar ?"

\section{TINJAUAN PUSTAKA}

\section{Investasi}

Investasi pada dasarnya adalah uang yang dipakai untuk menghasilkan uang. Untuk maksud itu, uang ditanam dalam objek yang dapat memberikan hasil berupa keuntungan. Sebagaimana yang dikemukakan oleh Sunariyah (2004:4) bahwa investasi adalah penanaman modal untuk satu atau lebih aktiva yang dimiliki dan biasanya berjangka waktu lama dengan harapan mendapatkan keuntungan di masa yang akan datang.

Menurut Halim (2005:4) investasi pada hakekatnya merupakan penempatan sejumlah dana pada saat sekarang dengan harapan untuk memperoleh keuntungan pada masa mendatang. Menurut Kasmir (2005:8) investasi adalah penanaman modal dalam suatu kegiatan yang memiliki jangka waktu relatif panjang dalam berbagai bidang usaha.

Berdasarkan beberapa definisi di atas dapat disimpulkan bahwa suatu investasi yang dilakukan merupakan pengorbanan sejumlah modal pada waktu sekarang yang diharapkan akan menghasilkan atau memberikan keuntungan pada waktu yang akan datang. Atas dasar inilah perlu adanya analisis terhadap usulan investasi secara baik. Hal ini dilakukan dengan membuat skala prioritas terhadap investasi yang memungkinkan akan memberikan hasil yang terbaik.

Mulyadi menggolongkan jenis-jenis investasi sebagai berikut:

1. Investasi yang tidak menghasilkan laba (non-profit investment)

Investasi jenis ini timbul karena adanya peraturan pemerintah atau karena syarat-syarat kontrak yang telah disetujui, yang mewajibkan perusahaan untuk melaksanakannya tanpa mempertimbangkan laba atau rugi.

2. Investasi yang tidak dapat diukur labanya (non-measurable profit investment) Investasi ini dimaksudkan untuk menaikkan laba, namun laba yang diharapkan akan diperoleh perusahaan dengan adanya investasi ini sulit untuk dihitung secara teliti.

3. Investasi dalam penggantian ekuipmen (replacement investment)

Investasi jenis ini meliputi pengeluaran untuk penggantian mesin dan ekuipmen yang ada. Dalam pemakaian mesin dan ekuipmen, pada suatu saat akan terjadi 
biaya operasi mesin dan ekuipmen menjadi lebih besar dibandingkan dengan biaya operasi jika mesin tersebut diganti dengan yang baru, atau produktifitasnya tidak lagi mampu memenuhi kebutuhan. Pada saat ini operasi dengan menggunakan mesin dan ekuipmen yang ada menjadi tidak ekonomis lagi.

4. Investasi dalam perluasan usaha (expansion investment)

Investasi jenis ini merupakan pengeluaran untuk menambah kapasitas produksi atau operasi menjadi lebih besar dari sebelumnya. Tambahan kapasitas akan memerlukan aktiva diferensial berupa tambahan investasi dan akan menghasilkan pendapatan diferensial yang berupa tambahan pendapatan, serta memerlukan biaya diferensial yang berupa tambahan biaya karena tambahan kapasitas.

\section{Aktiva Tetap}

Setiap perusahaan pasti mempunyai aktiva tetap baik aktiva tetap berwujud maupun aktiva tetap tidak berwujud. Aktiva tetap mempunyai peranan yang sangat penting dalam suatu perusahaan. Hal ini dilihat dari jumlah seluruh aktiva tetap tersebut dibandingkan dengan jumlah seluruh aktiva yang dimiliki perusahaan. Namun arti pentingnya aktiva tetap tersebut bagi suatu perusahaan dengan perusahaan lainnya berbeda tergantung dari jenis, sifat dan macam usaha yang dijalankannya seperti aktiva tetap yang dimilki oleh perusahaan jasa berbeda dengan aktiva tetap yang dimiliki oleh perusahaan dagang, perusahaan manufaktur dan sebagainya.

Pengertian aktiva tetap menurut Soemarso (2002:233) adalah aktiva bernilai besar yang sifatnya tetap atau permanen yang digunakan dalam kegiatan perusahaan dan tidak dijual kembali dalam kegiatan normal. Menurut Ikatan Akuntansi Indonesia (IAI) dalam PSAK NO.16 (2004:162) bahwa aktiva tetap adalah aktiva tetap berwujud yang diperoleh dalam bentuk siap pakai atau dengan dibangun lebih dahulu yang digunakan dalam operasi perusahaan, tidak dimaksudkan untuk dijual dalam rangka kegiatan normal perusahaan dan mempunyai masa manfaat lebih dari satu tahun. Sementara itu Mulyadi (2001:591) mengemukakan pengertian aktiva tetap sebagai kekayaan perusahaan yang memiliki wujud, mempunyai manfaat ekonomi lebih dari satu tahun dan diperoleh perusahaan untuk melaksanakan kegiatan perusahaan, bukan untuk dijual kembali.

Dari definisi di atas, maka dapat disimpulkan bahwa aktiva tetap pada dasarnya mempunyai karakteristik sebagi berikut:

1. Digunakan untuk operasi perusahaan dan tidak untuk dijual

2. Mempunyai masa manfaat lebih dari satu tahun

3. Mempunyai wujud atau bentuk fisik

4. Merupakan pengeluaran yang besar bagi perusahaan tersebut 


\section{Investasi Aktiva Tetap}

\section{Perputaran Dana yang Diinvestasikan dalam Aktiva Tetap}

Bambang Riyanto (2001:115) mengemukakan bahwa dana yang ditanamkan dalam aktiva tetap seperti halnya dana yang diinvestasikan dalam aktiva lancar juga mengalami perputaran. Secara konsepsional sebenarnya tidak ada perbedaannya antara investasi dalam aktiva tetap dengan investasi dalam aktiva lancar.

Suatu perusahaan mengadakan investasi dalam inventory, piutang dan lainlain mempunyai harapan agar dapat memperoleh kembali dana yang telah diinvestasikan dalam aktiva tersebut. Demikian pula halnya apabila perusahaan mengadakan investasi dalam aktiva tetap juga dengan harapan yang sama dengan investasi dalam aktiva lancar, yaitu bahwa perusahaan akan dapat memperoleh kembali dana yang ditanamkan dalam aktiva tetap tersebut.

Perbedaannya terdapat pada perputaran dana yang ditanamkan dalam aktiva tersebut. Pada aktiva lancar, jangka waktu terikatnya dana kurang dari satu tahun. Sebaliknya investasi pada aktiva tetap, dana yang tertanam didalamnya akan diterima kembali seluruhnya oleh perusahaan dalam waktu beberapa tahun kemudian dan secara berangsur-angsur. Dengan demikian, perbedaan antara investasi dalam aktiva tetap dan aktiva lancar adalah terletak dalam hal waktu dan cara perputaran dana yang tertanam didalamnya.

\section{Metode Penilaian Investasi}

Pada dasarnya inti dari suatu analisis penilaian investasi adalah untuk mengetahui sampai sejauh mana investasi yang dilakukan layak diterima untuk dilaksanakan atau tidak. Untuk menentukan usulan investasi mana yang akan diterima atau ditolak, maka usulan investasi tersebut harus dinilai.

Adapun metode penilaian investasi yang paling sering digunakan, adalah:

1. Metode PayBack Period (PP)

Halim (2003:134) mengemukakan bahwa Payback Period adalah jangka waktu yang dibutuhkan untuk mengembalikan nilai investasi melalui penerimaanpenerimaan yang dihasilkan oleh proyek investasi tersebut. Dengan demikian Payback Period dari suatu investasi menggambarkan panjangnya waktu yang akan diperlukan agar dana yang tertanam dalam suatu investasi dapat diperoleh kembali seutuhnya. Rumus Payback Period jika cash flow per tahun jumlahnya berbeda adalah:

$$
\text { Payback Period }=\mathrm{n}+\frac{\mathrm{a}-\mathrm{b}}{\mathrm{c}-\mathrm{b}} \times 1 \text { tahun }
$$

Di mana:

$\mathrm{n}=$ tahun terakhir di mana jumlah cash flow masih belum bisa menutupi original investment

$a=$ jumlah original investment 
$\mathrm{b}=$ jumlah kumulatif cash flow pada tahun ke $\mathrm{n}$

$c=$ jumlah kumulatif cash flow pada tahun ke $n+1$

Sedangkan rumus Payback Period yang digunakan jika cash flow per tahun jumlahnya sama adalah:

$$
\text { Payback Periode }=\frac{\text { Orginal Investment }}{\text { Cash Flow }} \text { x 1thn }
$$

Halim (2003:135) mengemukakan bahwa suatu usaha investasi akan diterima jika Payback Period yang dihasilkan lebih kecil dari yang disyaratkan. Sebaliknya, jika Payback Period yang dihasilkan lebih besar dari yang disyaratkan, maka investasi tersebut ditolak. Jika invsetasi tersebut lebih dari satu maka yang dipilih adalah investasi yang menghasilkan Payback Period yang paling kecil.

Metode Payback Period memiliki kelebihan dan kekurangan. Adapun kelebihan dan kekurangan metode ini menurut Soeharto (2002:126) yaitu:

- Kelebihan metode Payback Period:

- Metode ini cukup sederhana dan mudah dimengerti

- Untuk menilai suatu usulan investasi yang memerlukan modal dalam jumlah yang relatif besar

- Kekurangan metode Payback Period:

- Digunakan untuk mengukur kecepatan kembalinya dana dan tidak mengukur keuntungan proyek tersebut

o Mengabaikan benefit yang diperoleh sesudah dana investasi itu kembali

2. Metode Net Present Value (NPV)

Dengan diketahuinya kelemahan-kelemahan yang ada pada metode Payback Period maka muncullah metode lain yaitu metode Net Present Value (NPV). Metode ini menggunakan pertimbangan bahwa nilai uang sekarang lebih tinggi bila dibandingkan dengan nilai uang pada waktu mendatang, karena adanya faktor bunga.

Halim (2003:136) mengemukakan bahwa Net Present Value (NPV) merupakan metode yang digunakan untuk mengetahui layak tidaknya suatu investasi yang dilakukan dengan membandingkan nilai tunai dari arus kas yang akan diterima di masa yang akan datang dengan nilai investasi yang ditanamkan sekarang. Menurut Halim (2003:136) rumus yang digunakan untuk menghitung nilai NPV, yaitu :

$$
\mathrm{NPV}=\left\{\frac{\mathrm{CF}_{1}}{(1+\mathrm{i})^{1}}+\frac{\mathrm{CF}_{2}}{(1+\mathrm{i})^{1}}+\frac{\mathrm{CF}_{3}}{(1+\mathrm{i})^{3}}+\cdots+\frac{\mathrm{CF}_{\mathrm{n}}}{(1+\mathrm{i})^{\mathrm{n}}}\right\}-\mathrm{OI}
$$

Di mana :

NPV $=$ Net Present Value

$\mathrm{CF}_{1}, \mathrm{CF}_{2}, \mathrm{CF}_{3}, \mathrm{CF}_{\mathrm{n}}=$ Cash Flow Tahun 1, 2, 3 sampai ke-n

$\mathrm{i}=$ Interest rate

$\mathrm{n}=$ umur proyek investasi 
OI = Original Investment

Menurut Halim (2003:136) jika hasil perhitungan Net Present Value lebih dari 0 (nol), dikatakan investasi tersebut feasible (layak) untuk dilaksanakan dan jika lebih kecil dari 0 (nol) tidak layak untuk dilaksanakan.

Kelebihan dan kelemahan metode NPV menurut Soeharto (2002:123) yaitu:

- Kelebihan metode Net Present Value (NPV) :

- Memasukkan faktor nilai waktu dari uang

- Mempertimbangkan semua arus kas proyek

- Mengukur besaran absolut dan bukan relatif, sehingga mudah mengikuti konstribusinya terhadap usaha meningkatkan kekayaan perusahaan atau pemegang saham.

- Kelemahan metode Net Present Value :

- Penentuan tingkat suku bunga memerlukan perhitungan yang teliti

- Jumlah nilai sekarang tidak dapat dibandingkan dari rencana investasi yang lain yang jumlah investasinya tidak sama

3. Metode Internal Rate of Return (IRR)

Menurut Bambang Riyanto (2001:129), Internal Rate of Return dapat didefenisikan sebagai tingkat bunga yang akan menjadikan jumlah nilai sekarang dari hasil yang diharapkan dapat diterima sama dengan jumlah nilai sekarang dari pengeluaran modal. Sedangkan pengertian Internal Rate of Return (IRR) menurut Halim (2003:140) adalah tingkat bunga yang dapat menjadikan NPV sama dengan nol, karena present value dari cash flow pada tingkat bunga tersebut sama dengan internal investasinya.

Adapun rumus yang dapat digunakan untuk menghitung Internal Rate of Return menurut Bambang Riyanto (2001:131) yaitu :

$$
\mathrm{r}=\mathrm{P}_{1-} \mathrm{C}_{1} \frac{\mathrm{P}_{2}-\mathrm{P}_{1}}{\mathrm{C}_{2}-\mathrm{C}_{1}}
$$

Di mana:

$r=$ Internal Rate of Return

P1 = Tingkat bunga ke 1

P2 = Tingkat bunga ke 2

C1 $=$ NPV ke 1

$\mathrm{C} 2=\mathrm{NPV}$ ke 2

Halim (2003:139) mengatakan bahwa suatu investasi diterima jika IRRnya lebih besar atau sama dengan cost of capital/ interest rate/ required rate of return. Sebaliknya, suatu rencana investasi ditolak jika IRRnya lebih kecil dari cost of capital/ interest rate/ required rate of return. Jika rencana investasi tersebut lebih dari satu, maka yang diterima adalah yang menghasilkan IRR paling besar. Kelebihan dan kekurangan metode ini menurut Soeharto (2002 :128): 
- Kelebihan metode Internal Rate of Return:

- Mempertrimbangkan nilai waktu dari uang

- Mempertimbangkan semua aliran kas selama masa investasi

- Kekurangan metode Internal Rate of Return:

- Jika terjadi kenaikan tingkat suku bunga selama masa investasi maka Internal Rate of Return yang telah ditentukan sebelumnya tidak dapat disesuaikan

\section{METODE PENELITIAN}

\section{Lokasi Penelitian}

Adapun yang menjadi objek penelitian dalam penulisan adalah PT. Taspi TRD COY. PT. Taspi Trading Company atau lebih dikenal dengan nama PO. PIPOSS. PO. PIPOSS merupakan akronim dari Perusahaan Otobis Padaidi Padaelo Sipatuo Sipatokkong, di kota makassar.

\section{Definisi Operasional Variabel}

Definisi operasional variabel merupakan batasan-batasan yang dipakai penulis untuk menghindari adanya interpretasi yang berbeda terhadap variabel yang diteliti sehingga setiap variabel perlu didefinisikan. Adapun definisi dari variabel penelitian ini yaitu:

1. Kelayakan Rencana Investasi Aktiva Tetap adalah suatu penilaian mengenai layak atau tidak atas suatu rencana penambahan aktiva tetap yang dilakukan oleh PT. Taspi TRD COY yang berupa penambahan armada bus. Sebelum melakukan penambahan aktiva tetap terlebih dahulu dilakukan suatu penilaian investasi untuk menilai kelayakan investasi tersebut.

2. Perluasan usaha adalah pengembangan usaha yang dilakukan oleh PT. Taspi TRD COY dengan cara menambah armada bus yang sekarang ini berjumlah 40 unit armada dan rencananya akan dilakukan penambahan sebanyak 3 unit armada.

\section{Teknik Pengumpulan Data}

Adapun teknik pengumpulan data yang digunakan dalam penelitian ini adalah: 1) Observasi, 2) Dokumentasi, dan 3) Wawancara.

\section{Teknik Analisis Data}

Penulis menggunakan teknik analisis deskriptif yaitu menggambarkan dan menguraikan penilaian rencana investasi berdasarkan data-data yang dimiliki oleh PT. Taspi TRD COY. Adapun alat analisis data yang digunakan penulis untuk menganalisis permasalahan yang dihadapi dalam penelitian ini yaitu metode Net Present Value (NPV) karena metode ini merupakan kriteria kelayakan investasi yang paling banyak digunakan untuk mengetahui kelayakan atau ketidaklayakan investasi dalam suatu usaha. Selain itu metode ini juga mempertimbangkan nilai waktu dari uang. 
Metode NPV digunakan untuk mengetahui layak tidaknya suatu investasi yang dilakukan dengan membandingkan nilai tunai dari arus kas yang akan diterima di masa yang akan datang dengan nilai investasi yang ditanamkan sekarang. Dengan menggunakan rumus:

$\mathrm{NPV}=\left\{\frac{\mathrm{CF}_{1}}{(1+\mathrm{i})^{1}}+\frac{\mathrm{CF}_{2}}{(1+\mathrm{i})^{1}}+\frac{\mathrm{CF}_{3}}{(1+\mathrm{i})^{3}}+\cdots+\frac{\mathrm{CF}_{\mathrm{n}}}{(1+\mathrm{i})^{\mathrm{n}}}\right\}-\mathrm{OI}$

Di mana :

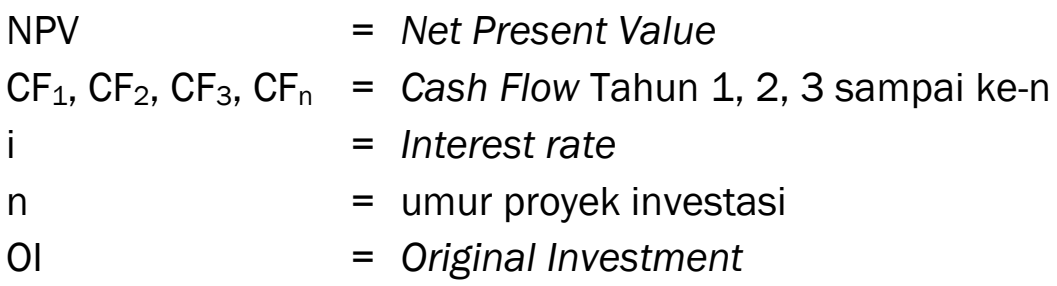

\section{HASIL PENELITIAN}

\section{Pelaksanaan Kelayakan Investasi Usaha Angkutan PT. Taspi TRD COY}

Sebagaimana yang telah dikemukakan sebelumnya bahwa usaha angkutan PT. Taspi TRD COY merencanakan melakukan investasi untuk memperluas kegiatan operasionalnya mengingat peluang yang dimiliki cukup besar yaitu adanya peningkatan permintaan sementara armada yang beroperasi masih kurang. Rencana investasi yang akan dilakukan adalah dengan mengadakan penambahan armada bus sebanyak 3 (tiga) unit yang nantinya akan digunakan untuk kegiatan operasional perusahaan.

Dengan adanya penambahan tersebut maka perusahaan mengharapkan akan memperoleh keuntungan agar kontinuitas perusahaan dapat dipertahankan, sekaligus memberikan manfaat yang besar bagi masyarakat. Adapun sumber dana yang akan digunakan adalah sebagian dari modal sendiri dan sebagian lagi dari pinjaman dari Bank.

Dalam menilai kelayakan suatu investasi perlu dibuat proyeksi cahs flow dan untuk membuat proyeksi cash flow terlebih dahulu kita harus membuat proyeksi laporan rugi laba. Proyeksi laporan rugi laba memperlihatkan jumlah pendapatan dan biaya-biaya yang akan diperkirakan akan terjadi pada tahun yang akan datang. Proyeksi laporan rugi laba ini tidak hanya bermanfaat bagi pihak manajemen perusahaan sendiri, tetapi juga seringkali dibutuhkan oleh para pemegang dan calon pemegang saham perusahaan., karena laporan yang diproyeksikan tersebut akan dapat memberikan informasi-informasi sehubungan dengan perkiraan kondisi keuangan perusahaan pada tahun berikutnya. Proyeksi laporan rugi laba ini dibuat berdasakan atas laporan keuangan dari PT. Taspi TRD COY tahun 2014 sampai tahun 2016. 
1. Proyeksi Laporan Rugi Laba

Komponen-komponen yang diperhitungkan dalam proyeksi rugi laba dapat diperinci sebagai berikut:

a. Pendapatan

Yang dimaksud dengan pendapatan di sini adalah total pendapatan jasa untuk 3 (tiga) unit armada bus selama umur investasi dan diproyeksikan akan mengalami kenaikan sebesar $10 \%$ setiap tahunnya. Data yang diperoleh berdasarkan pengalaman perusahaan bahwa rata-rata pendapatan jasa perhari perunit bus adalah sebesar Rp 3.000.000,-. Jadi pendapatan jasa untuk 3 (tiga) unit armada bus pada tahun pertama adalah:

Rp 3.000.000,- x 360 hari $\times 3$ unit $=$ Rp 3.240.000.000,-

Dengan demikian, pendapatan jasa untuk setiap tahun dengan kenaikan 10\% dapat diproyeksikan sebagai berikut:

Tahun I = Rp 3.240.000.000,-

Tahun II = Rp 3.564.000.000,--

Tahun III = Rp 3.920.400.000,-

Tahun IV = Rp 4.312.440.000,-

Tahun $\mathrm{V}=\operatorname{Rp}$ 4.473.684.000,-

b. Biaya-biaya Operasional

1) Biaya pemakaian BBM

Rata-rata pemakaian BBM untuk satu hari diperkirakan 188 liter per unit, dengan harga per liter Rp 4.500,- dan diperkirakan harga BBM akan mengalami kenaikan sebesar 10\% setiap tahun. Jadi biaya pemakaian BBM untuk 3 (tiga) unit armada bus per tahun diproyeksikan sebagai berikut:

188 liter x Rp 4.500,- $\times 360$ hari x 3 unit = Rp 913.680.000,-

Tahun I $=\operatorname{Rp} 913.680 .000,-$

Tahun II $\quad=$ Rp 1.005.048.000,-

Tahun III = Rp 1.105.552.800,-

Tahun IV $\quad=\operatorname{Rp~1.216.108.080,-~}$

Tahun V = Rp 1.337.718.888,-

2) Biaya pemakaian oli

Rata-rata pemakaian oli mesin per unit 125 liter per bulan, harga per liter Rp 8.000 ,- dan diasumsikan harga ini akan mengalami kenaikan sebesar $10 \%$ per tahun. Jadi biaya pemakaian oli untuk 3 (tiga) unit armada bus diproyeksikan sebagai berikut:

125 liter $\times \operatorname{Rp} 8000 \times 12 \times 3$ unit $=\mathrm{Rp} 36.000 .000,-$

Tahun I = Rp 36.000.000,-

Tahun II = Rp 39.600.000,-

Tahun III = Rp 43.560.000,- 
Tahun IV = Rp 47.916.000,-

Tahun $V=\operatorname{Rp} 52.707 .600,-$

3) Biaya pemakaian spare parts

Biaya pemakaian spare parts diperkirakan menghabiskan biaya sebesar Rp 90.000.000,- per tahun dengan kenaikan $10 \%$ setiap tahun.

Tahun I = Rp 90.000.000,--

Tahun II = Rp 99.000.000,-

Tahun III = Rp 108.900.000,-

Tahun IV = Rp 119.790.000,-

Tahun V = Rp 131.769.000,-

4) Biaya gaji sopir

Biaya gaji sopir ditetapkan sebesar $7 \%$ dari total pendapatan. Jadi biaya gaji untuk sopir setiap tahun diproyeksikan sebagai berikut:

Tahun I = Rp 226.800.000,--

Tahun II = Rp 249.480.000,-

Tahun III = Rp 274.428.000,-

Tahun IV = Rp 301.870.800,-

Tahun V = Rp 313.157.880,-

5) Biaya izin dan surat-surat mobil

Biaya izin dan surat-surat mobil per tahun sebesar Rp 15.000.000,- dan biaya ini diasumsikan tidak mengalami perubahan sampai akhir umur investasi.

6) Biaya asuransi kendaraan

Biaya asuransi kendaraan untuk 3 (tiga) unit armada bus ditetapkan sebesar Rp 15.000.000,- per tahun dan diasumsikan tidak mengalami perubahan sampai akhir umur investasi.

7) Biaya astek sopir

Astek yang ditetapkan sebesar Rp 1.692.000,- per tahun dan relatif sama setiap tahun.

8) Biaya perbaikan dan pemeliharaan

Biaya perbaikan dan pemaliharaan untuk 3 (tiga) unit armada bus diperkirakan sebesar Rp 40.000.000,- pada tahun pertama dan biaya ini diasumsikan akan mengalami kenaikan sebesar $5 \%$ per tahun.

Tahun I = Rp 40.000.000,-

Tahun II = Rp 42.000.000,-

Tahun III = Rp 44.100.000,-

Tahun IV = Rp 46.305.000,-

Tahun V = Rp 48.620.250,- 
9) Biaya penyusutan

Metode yang digunakan dalam menghitung penyusutan kendaraan adalah metode garis lurus, yaitu metode yang dianggap penyusutan tiap tahun adalah sama. Umur investasi ditetapkan 5 (lima) tahun. Jadi biaya penyusutan:

$$
\frac{\mathrm{Rp} 3.600 .000 .000}{5}=\operatorname{Rp} 720.000 .000
$$

10) Pajak perseroan

Menurut Undang-Undang Pajak Penghasilan (pph 21) dikenakan sebesar:

a) Penghasilan di bawah Rp 10.000.000,- dikenakan pajak $10 \%$

b) Penghasilan antara $\mathrm{Rp} 10.000 .000$,- sampai $\mathrm{Rp} 50.000 .000$, dikenakan pajak $15 \%$

c) Penghasilan di atas Rp 50.000.000,-dikenakan pajak 30\%

Untuk lebih jelas dapat dilakukan perhitungan sebagai berikut:

Tahun I:

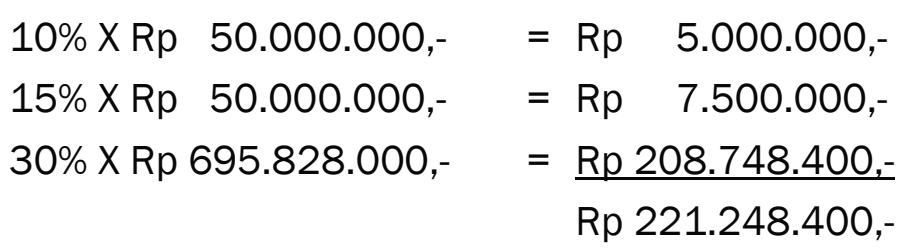

Tahun II:

$10 \% \times \mathrm{Rp} 50.000 .000,-\quad=\operatorname{Rp} 5.000 .000,-$

$15 \% \times \operatorname{Rp} 50.000 .000,-\quad=\operatorname{Rp~7.500.000,-}$

$30 \% \times \operatorname{Rp} 842.580 .000,-\quad=\underline{R p ~ 252.774 .000,-}$

Rp 265.274.000,-

Tahun III:

$10 \% \times \operatorname{Rp} 50.000 .000,-\quad=\operatorname{Rp} 5.000 .000,-$

$15 \% \times \operatorname{Rp} 50.000 .000,-\quad=\operatorname{Rp~7.500.000,-}$

$30 \%$ X Rp 1.004.107.200,- $=\underline{\operatorname{Rp} 301.232 .160,-}$

Rp 313.732.160,-

Tahun IV:

$10 \% \times R p \quad 50.000 .000,-\quad=R p \quad 5.000 .000,-$

$15 \% \times \operatorname{Rp} 50.000 .000,-\quad=\operatorname{Rp} 7.500 .000,-$

$30 \%$ X Rp 1.181.902.120,- $=\operatorname{Rp~354.570.636,-}$

Tahun V:

Rp 367.070.636

$10 \% \times \operatorname{Rp} \quad 50.000 .000,-=\operatorname{Rp} 5.000 .000,-$

$15 \% \times \operatorname{Rp} \quad 50.000 .000,-=\operatorname{Rp} 7.500 .000,-$

$30 \%$ X RP 1.166.966.382,- $=\underline{R p ~ 350.089 .914,6 ~}$

Rp 362.589.914,6 
Berdasarkan data-data diatas, maka untuk lebih jelasnya proyeksi biaya-biaya dapat dilihat pada tabel 2.

Tabel 2. Proyeksi Biaya-Biaya PT. Taspi TRD COY untuk Tahun I, II, III, IV, dan V (Dalam Rupiah)

\begin{tabular}{|l|c|c|c|c|c|}
\hline URAIAN & \multicolumn{1}{|l|}{ II } & III & IV & V \\
\hline $\begin{array}{l}\text { Biaya pemakaian } \\
\text { BBM }\end{array}$ & $913.680 .000,-$ & $1.005 .048 .000,-$ & $1.105 .552 .800,-$ & $1.216 .108 .080,-$ & $1.337 .718 .888,-$ \\
\hline $\begin{array}{l}\text { Biaya pemakaian } \\
\text { oli mesin }\end{array}$ & $36.000 .000,-$ & $39.600 .000,-$ & $43.560 .000,-$ & $47.916 .000,-$ & $52.707 .600,-$ \\
\hline Biaya spare parts & $90.000 .000,-$ & $99.000 .000,-$ & $108.900 .000,-$ & $119.790 .000,-$ & $131.769 .000,-$ \\
\hline Biaya gaji sopir & $226.800 .000,-$ & $249.480 .000,--$ & $274.428 .000,-$ & $301.870 .800,-$ & $313.157 .880,-$ \\
\hline $\begin{array}{l}\text { Biaya izin dan } \\
\text { surat-surat mobil }\end{array}$ & $15.000 .000,-$ & $15.000 .000,-$ & $15.000 .000,-$ & $15.000 .000,-$ & $15.000 .000,-$ \\
\hline $\begin{array}{l}\text { Biaya asuransi } \\
\text { kendaraan }\end{array}$ & $15.000 .000,-$ & $15.000 .000,-$ & $15.000 .000,-$ & $15.000 .000,-$ & $15.000 .000,-$ \\
\hline Biaya astek sopir & $1.692 .000,-$ & $1.692 .000,--$ & $1.692 .000,-$ & $1.692 .000,-$ & $1.692 .000,-$ \\
\hline $\begin{array}{l}\text { Biaya perbaikan } \\
\text { dan } \\
\text { pemeliharaan }\end{array}$ & $40.000 .000,-$ & $42.000 .000,-$ & $44.100 .000,--$ & $46.305 .000,-$ & $48.620 .250,-$ \\
\hline Biaya penyusutan & $720.000 .000,-$ & $720.000 .000,-$ & $720.000 .000,-$ & $720.000 .000,--$ & $720.000 .000,-$ \\
\hline Total biaya & $2.058 .172 .000,-$ & $2.186 .820 .000,-$ & $2.328 .232 .800,-$ & $2.483 .671 .880,-$ & $2.635 .665 .018,-$ \\
\hline
\end{tabular}

Sumber: PT. Taspi TRD COY, data telah diolah

Setelah proyeksi pendapatan dan biaya-biaya telah dibuat, maka lebih lanjut dapat dibuatkan proyeksi laporan rugi laba. Proyeksi laporan rugi laba merupakan proyeksi laporan keuangan untuk beberapa periode yang akan memberikan gambaran atas penghasilan yang diharapkan akan diterima serta biaya-biaya yang diperkirakan akan dikeluarkan selama umur ekonomis suatu investasi. Adapun proyeksi laporan rugi laba PT. Taspi dapat dilihat pada tabel 3.

\section{c. Proyeksi Cash Flow}

Proyeksi cash flow memberikan gambaran mengenai jumlah dana yang tersedia setiap saat yang dipakai baik berbagai kebutuhan operasional perusahaan misalnya investasi, maupun jumlah pemasukan dan pengeluaran yang disusun dengan menelusuri dan mengkaji laporan laba rugi. Dalam cash flow semua data pendapatan yang diterima dengan biaya yang dikeluarkan baik jenis maupun jumlahnya diestimasi sedemikian rupa sehingga menggambarkan pemasukan dan pengeluaran di masa yang akan datang.

Untuk menghitung cash flow dapat dilakukan dengan menggunakan cara sebagi berikut:

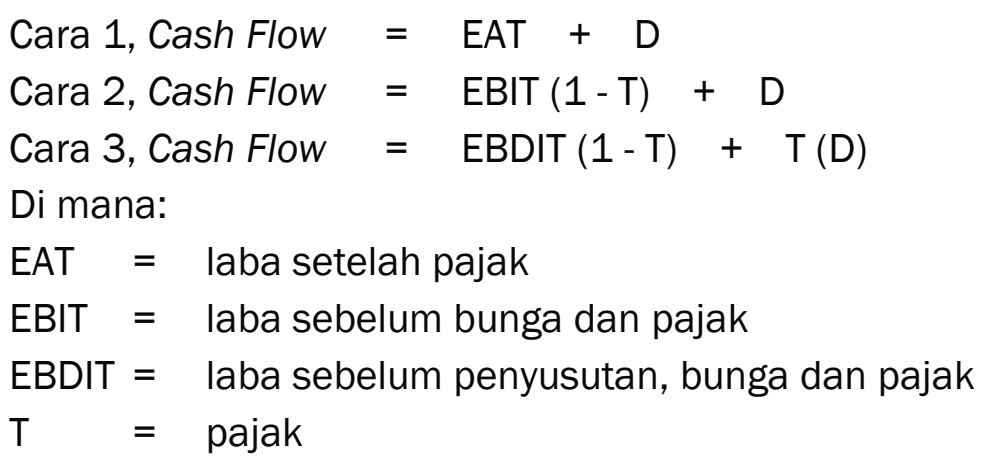


$\mathrm{D}=$ penyusutan

Dengan demikian proyeksi cash flow dari usaha angkutan PT. Taspi TRD COY dapat kita lihat pada tabel 4.

Tabel 4. Proyeksi Cash Flow PT. Taspi TRD COY Tahun I, II, III, IV, dan V (Dalam Rupiah)

\begin{tabular}{|c|c|c|c|c|c|}
\hline URAIAN & I & II & III & IV & V \\
\hline Pendapatan & $3.240 .000 .000,-$ & $3.564 .000 .000,-$ & $3.920 .400 .000,-$ & $4.312 .440 .000,-$ & $4.743 .684 .000,-$ \\
\hline $\begin{array}{c}\text { Biaya } \\
\text { operasional }\end{array}$ & $2.058 .172 .000,-$ & $2.186 .820 .000,-$ & $2.415 .232 .800,-$ & $2.581 .691 .880,-$ & $2.762 .376 .618,-$ \\
\hline EBDIT & $1.181 .828 .000,-$ & $1.377 .180 .000,-$ & $1.505 .167 .200,-$ & $1.730 .748 .120,-$ & $1.981 .307 .382,-$ \\
\hline $\begin{array}{c}\text { Cash flow }= \\
\text { EBDIT (1-T) + T } \\
\text { (D) }\end{array}$ & $1.043 .279 .600,-$ & $1.180 .026 .000,-$ & $1.269 .617 .040,-$ & $1.427 .523 .684,-$ & $1.602 .915 .167,-$ \\
\hline
\end{tabular}

Sumber: PT. Taspi TRD COY, data telah diolah.

\section{Analisis Penelitian Investasi Usaha Angkutan PT. TASPI TRD COY}

Dalam menganalisis usulan investasi yang digunakan di sini adalah metode Net Present Value yang merupakan metode yang digunakan untuk mengetahui layak tidaknya suatu investasi yang dilakukan dengan membandingkan nilai tunai dari arus kas akan diterima di masa yang akan datang dengan nilai investasi yang ditanamkan sekarang.

Untuk mengetahui layak atau tidaknya investasi yang dilakukan oleh PT. Taspi TRD COY yang berupa penambahan 3 (tiga) unit armada bus maka dapat dihitung seperti pada table 5 .

Tabel 5. Perhitungan NPV atas Investasi PT.Taspi TRD COY (dalam Rupiah)

\begin{tabular}{|c|c|c|c|}
\hline Tahun & $\begin{array}{c}\text { Cash Flow } \\
\text { (Rp) }\end{array}$ & $\begin{array}{c}\text { Interest Rate } \\
(\mathbf{1 5 \% )}\end{array}$ & $\begin{array}{c}\text { Present Value } \\
\text { (Rp) }\end{array}$ \\
\hline I & $1.043 .279 .600,-$ & 0,8696 & $907.235 .940,2$ \\
\hline II & $1.180 .026 .000,-$ & 0,7561 & $892.217 .658,6$ \\
\hline III & $1.330 .517 .040,-$ & 0,6575 & $874.814 .953,8$ \\
\hline IV & $1.496 .137 .684,-$ & 0,5718 & $855.491 .527,7$ \\
\hline V & $1.502 .613 .287,-$ & 0,4972 & $747.099 .326,5,-$ \\
\hline Total Present Value & & $4.276 .859 .407,-$ \\
Original Investment & & $3.600 .000 .000,-$ \\
\hline \multicolumn{2}{l|}{ Net Present Value } & $676.859 .406,8,-$ \\
\hline
\end{tabular}

Untuk perhitungan NPV atas investasi yang dilakukan oleh PT. Taspi TRD COY, jumlah cash flow dapat dilihat pada table 4 di mana cash flow pada tahun pertama sebesar Rp 1.043.279.600,- dikali dengan tingkat suku bunga (interest rate) 0,8696 (tingkat suku bunganya diasumsikan sebesar 15\%, dapat dilihat pada tabel 
PV pada lampiran) sehingga diperoleh jumlah Present Value pada tahun pertama sebesar Rp 907.235.940,2 dari hasil penjumlahan Present Value secara keseluruhan diperoleh total nilai sekarang sebesar Rp 4.276.859.407 di mana total nilai sekarang dikurang modal awal sebesar Rp 3.600.000.000,- maka diperoleh nilai bersih (Net Present Value) sebesar Rp 676.859.406,8,-

Berdasarkan hasil perhitungan Net Present Value (NPV) di atas, menunjukkan bahwa usulan investasi yang akan dilaksanakan oleh PT. Taspi TRD COY dinyatakan dapat diterima atau layak dilaksanakan karena NPV-nya menunjukkan hasil yang positif sebesar Rp 676.859.406,8,- Dengan demikian dapat diartikan bahwa dana sebesar Rp 3.600.000.000,- yang diinvestasikan dalam perluasan usaha tersebut dapat menghasilkan present value cash flow sebesar Rp 4.276.859.407

\section{DAFTAR PUSTAKA}

Baridwan, Zaki. 1992. Intermediate AccountingEdisi 7, Yogyakarta: BPFE Halim, Abdul. 2003. Analisis Investasi, Jakarta: Salemba 4 Husnan, Suad \& Suwarsono. 2000. Studi Kelayakan Proyek, Yogyakarta: YPKN Ikatan Akuntansi Indonesia. 2004. Standar Akuntansi Keuangan, Jakarta: Salemba 4.

Kasmir \& Jakfar. 2007. Studi Kelayakan Bisnis, Jakarta: Kencana Prenada Media Group

Mulyadi. 1997. Akuntansi Manajemen: Konsep, Manfaat Dan Rekayasa, Edisi 2, Yogyakarta: YKPN

Bambang Riyanto, Bambang. 2001. Dasar-Dasar Pembelanjaan Perusahan Edisi 7 , Yogyakarta: BPFE

Soeharto, Iman. 2002. Studi Kelayakan Proyek Industri. Jakarta : Erlangga

Soemarso S.R, 2002. Akuntansi Suatu Pengantar Edisi 5, Jakarta: Salemba 4

Sugiyono, 2005. Metode Penelitian Alternatif. Bandung : Alfa Beta

sunariyah, Rani Setiani. 2007. Pengembangan Usaha Dengan Menambah Cakupan Usaha.

(online). (http: www.perluasan usaha. Blogspot. com, diakses 3 Mei 2009

Tandellin, Eduardus. Analisis Investasi Dan Manajemen Portofolio, Edisi 1, Yogyakarta: BPFE. 